\title{
HPV clearance in postpartum period of HIV-positive and negative women: a prospective follow-up study
}

\author{
Emilia Moreira Jalil ${ }^{1 *}$, Francisco Inacio Bastos ${ }^{1,2}$, Patricia Pereira dos Santos Melli ${ }^{3}$, Geraldo Duarte ${ }^{3}$, \\ Renata Toscano Simoes ${ }^{4}$, Aparecida Yulie Yamamoto ${ }^{3}$, Rodrigo Augustus Amaral de Morais ${ }^{4}$ \\ and Silvana Maria Quintana ${ }^{3}$
}

\begin{abstract}
Background: HPV persistence is a key determinant of cervical carcinogenesis. The influence of postpartum on HPV clearance has been debated. This study aimed to assess HPV clearance in later pregnancy and postpartum among HIV-positive and negative women.

Methods: We conducted a follow-up study with 151 HPV-positive women coinfected with HIV, in 2007-2010. After baseline assessment, all women were retested for HPV infection using PCR in later pregnancy and after delivery. Multivariable logistic regressions assessed the putative association of covariates with HPV status in between each one of the successive visits.

Results: Seventy-one women (47\%) have eliminated HPV between the baseline visit and their second or third visits. HIV-positive women took a significantly longer time $(7.0 \pm 3.8$ months) to clear HPV, compared to those not infected by HIV (5.9 \pm 3.0 months). HPV clearance was significantly more likely to take place after delivery than during pregnancy $(84.5 \% \times 15.5 \%)$.

Conclusions: Both HIV-positive and negative women presented a significant reduction in HPV infection during the postpartum period. HIV-positive status was found to be associated with a longer period of time to clear HPV infection in pregnant women.
\end{abstract}

Keywords: Human Papillomavirus, HIV, Pregnancy, Postpartum Period, Polymerase Chain Reaction (PCR)

\section{Background}

Human papillomavirus (HPV) is highly prevalent in non-vaccinated sexually active women worldwide, even among those presenting normal cytology [1]. Most HPV infections are transient and self-limited. Up to $90 \%$ HPV infections are eliminated after 12-24 months [2-5]. Only $10-15 \%$ of women develop a persistent infection, which is one of the most important risk factors for cervical carcinogenesis [6-9]. Even short-time HPV persistence has been associated with higher risk for cervical intra-epithelial neoplasia, compared to women without a history of HPV infection [10,11].

\footnotetext{
* Correspondence: emjalii@hotmail.com

'ICICT/ENSP - Fundação Oswaldo Cruz - FIOCRUZ, Biblioteca de Manguinhos suite 229, Av. Brasil 4365, Rio de Janeiro RJ 21045-900, Brazil

Full list of author information is available at the end of the article
}

HPV clearance is more frequent in the first six months after prime infection, with rates of $50-70 \%$ per follow-up year $[5,12,13]$. Adequate cell immune response is crucial for HPV clearance $[14,15]$. On the other hand, immune tolerance/deficiency favours viral persistence and cervical cancer progression [16].

HIV-positive women have a higher risk of acquiring new HPV infections and a lower chance of clearing them compared to women not infected by HIV [17-21]. Markers of cell immunity system, e.g. higher CD4+ T cell counts, have been associated with HPV clearance in HIV-positive women $[21,22]$.

Changes in immunity and other biological parameters (e.g. changes in the levels of different hormones) during pregnancy and postpartum may modulate the natural history of HPV infection. Some recent studies did not

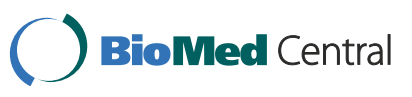

(c) 2013 Jalil et al.; licensee BioMed Central Ltd. This is an open access article distributed under the terms of the Creative Commons Attribution License (http://creativecommons.org/licenses/by/2.0), which permits unrestricted use, distribution, and reproduction in any medium, provided the original work is properly cited. 
observe differences in HPV status over time, during pregnancy [23-25]. Most authors, however, have found a reduction in HPV positivity during the postpartum period [26-29]. Minkoff et al. [30] evaluated HIV-positive women and documented higher numbers of new HPV types at the postpartum period than during pregnancy, but their study did not asses HPV clearance.

The dynamics of HPV infection during pregnancy is not well established and information remains scarce and controversial. Few studies have studied HPV clearance and persistence during and after pregnancy, and just one of them has prospectively evaluated HPV infection in HIV-positive women. In this study, we aimed to evaluate HPV clearance in the postpartum period of both HIVpositive and negative women.

\section{Methods}

A prospective follow-up study was carried out between January 2007 and January 2010, in Ribeirão Preto, São Paulo state, Brazil. Pregnant women were selected consecutively from the Prenatal Outpatient Clinic of the Infectious Diseases Unit, Obstetrics and Gynecology Department of the University Hospital, Medical School of Ribeirão Preto, University of São Paulo. This is a tertiary service, which follows-up with women previously diagnosed with HIV or HPV infection at primary units, selected from a large catchment population mainly composed of women from middle and low socioeconomic strata. Women were evaluated according to their HIV status and/or HPV-related lesion. HPV infection type was classified as clinical (in case of warts), subclinical (in case that colposcopic lesions were made evident), or HPV-positive (if only PCR-positive).

Inclusion criteria were as follows: 1 ) be in the 1st half of pregnancy; 2) be positive for HPV, as defined by a PCR exam; 3 ) be an adult ( $\geq 18$ years old; so in full capacity to consent or not to take part of the study according to Brazilian law); and 4) have read and signed the informed consent form.

Cervicovaginal samples (with $2 \mathrm{~mL}$ of saline solution) were collected from all women and tested for HPV by Polymerase Chain Reaction (PCR). Women who tested positive for HPV were re-evaluated at two subsequent visits: at the 2nd half of pregnancy and after delivery.

The study protocol was approved by the Ethics Review Board of the Ribeirao Preto's Medical School Hospital Sao Paulo University, and all women voluntarily signed informed consent before enrolment. All patients followed antenatal care routine of the service and no procedure was altered for those women enrolled in the study, except for the three PCR exams performed in each one of the visits (during that period, PCR was not a routine exam in the outpatient clinic).

Cervicovaginal samples were stored at $-80^{\circ} \mathrm{C}$ until DNA extraction, which was performed by QIAamp ${ }^{\circ}$ DNA Mini
Kit (Qiagen, USA). Consensus primers GP5+ / GP6+ were used to identify HPV positivity, as previously described [31]. After that, HPV types 6 and 11, considered low-risk HPV (LR-HPV) and 16, 18, 31 and 33, high-risk HPV (HR-HPV), were identified simultaneously by multiplex PCR using specific primers [32]. Every single woman had her HPV infection typed at least once. Primers S-GH20, pCO3 and pCO4 were used as internal controls [32,33]. Negative controls were included in every single step in order to minimize false positive results; positive controls used were known positive samples collected in previous studies and belonging to a panel of positive and negative controls.

Sample size was calculated with the help of Graphpad StatMate $^{\oplus}$ (Graphpad Software, USA). Assuming a 15\% differential clearance over time (from early pregnancy up to postpartum), it would be necessary to include at least 99 patients, considering an $80 \%$ power and an alpha of $5 \%$.

HPV clearance was defined as having at least one negative result after a confirmed positive one. A negative test detected in the 2 nd visit (followed by a negative one in the 3rd visit) was defined as "clearance", taking place between the 1 st and the 2 nd visit (i.e. clearance during pregnancy). Women with positive tests in the first and second visits, followed by a negative test in the 3rd visit, were defined as "clearance" occurring between the 2nd and the 3 rd visits (i.e. clearance during the postpartum period).

Persistent infection was defined for the sake of our study as "the consecutive detection of at least two positive HPV tests between the second and the third visit" (considering that all women tested positive at baseline). When a negative result appeared in between two positive tests (i.e. between the baseline and the third visit), the intermediate result was defined as a false negative, in agreement with previous studies and their respective criteria $[34,35]$. Duration of infection was estimated as the

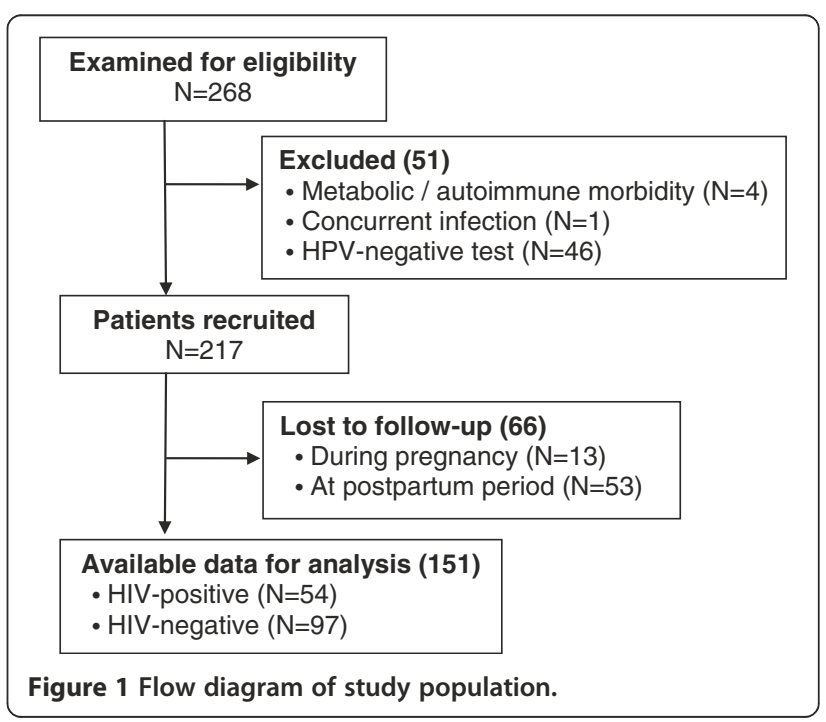


Table 1 Baseline characteristics of 151 HPV-positive women under follow-up, according to HIV status

Characteristics
Marital status
Non-stable
Stable

Race/skin color

White
Brown
Black

Years of education

$$
\begin{aligned}
& \text { 0-4 } \\
& \text { 5-8 }
\end{aligned}
$$$$
>9
$$

Menarche (years)

$$
\begin{aligned}
& <9 \\
& 9-15 \\
& >15
\end{aligned}
$$

Age at 1st sexual experience (years)

$$
\begin{aligned}
& <16 \\
& 16-20 \\
& >20
\end{aligned}
$$

Age of 1 st pregnancy (years)

$$
\begin{aligned}
& <16 \\
& 16-20 \\
& >20
\end{aligned}
$$

Parity

$$
\begin{aligned}
& 0 \\
& 1-3 \\
& \geq 4
\end{aligned}
$$

Lifetime no. of sex partners

$$
\leq 5
$$$$
\text { 6-10 }
$$$$
11-20
$$$$
>20
$$

$N=54$
HIV-positive women

29.6

70.4

48.2

33.3

18.5

13.0

44.4

42.6

Sex partners (last 12 mos.)

$$
\begin{aligned}
& <3 \\
& \geq 3
\end{aligned}
$$

Soking

Drug use

$$
\text { None }
$$$$
\text { Cocaine/crack }
$$

\section{Alcohol}

Previous STD

Sexual partner with STD ${ }^{1}$

635

HIV-negative women

$\mathrm{N}=97 \quad \%$

35

1


Table 1 Baseline characteristics of 151 HPV-positive women under follow-up, according to HIV status (Continued)

\begin{tabular}{lcccc}
\hline HPV infection type & & & & \\
HPV-positive & 32 & 59.3 & 8 & 62 \\
Subclinical & 22 & 40.7 & 27 & 63.9 \\
Clinical & 0 & 0 & 27 & 27.8 \\
\hline
\end{tabular}

period (in months) elapsed between the baseline visit and a mid-point between the baseline visit and the first negative result, in all cases where no positive result followed (i.e. a false negative).

Statistical analysis was carried out with the help of EpiInfo 3.5.3 (CDC, USA) and SAS 9.0 (SAS Institute, USA). Paired t-tests (with Welch correction whether unequal variances were made evident) and chi-square test (or Fisher Exact test for table cells with less than 5 events) were used for univariate analysis. Multiple log-binomial regression models were used, as the outcome was binary; procedure PROC GENMOD was applied for model adjustment. Multivariable analyses were controlled for participants' age, smoking/non-smoking, mode of delivery, HIV status, nature of HPV infection (clinically defined or otherwise), and HPV type (dichotomous variable: high vs. low risk).

\section{Results}

One hundred and fifty-one HPV-positive women were enrolled and followed-up with, of which 54 were HIVpositive and 97 were HIV-negative (Figure 1). Mean gestational age at entrance and at 2nd visit were $13.1 \pm 4.2$ and $32.6 \pm 5.0$ weeks, respectively. The mean visit interval did not differ significantly among HIV-positive $(5.47 \pm 2.6)$ and negative (5.0 \pm 2.1 months) women. Mean interval between the 1st and the 2nd visit was $17.1 \pm 6.3$ weeks and postpartum visit occurred $4.7 \pm 2.2$ months after delivery. On average, HIV-positive women were older than HIVnegative women $(28.6 \pm 6.1$ years vs. $23.2 \pm 6.4$ years $)$ and had a longer follow-up period $(9.6 \pm 3.2$ months vs. $7.8 \pm$ 2.9 months). Most women had vaginal deliveries (53.7\% of HIV-positive and $62.0 \%$ of HIV-negative women). HIVpositive women had a higher proportion of infections which were exclusively detected by PCR, compared to their HIV-negative counterparts (Table 1).

Overall genotype prevalences were as follows (in descending order of frequency): $37.1 \%$ (HPV 6 / 11), 23.8\% (HPV 18), 13.2\% (HPV 16), 4.0\% (HPV 31), and 4.0\% (HPV 33). None of these genotypes were identified in 43 samples (28.5\%). The socio-demographic characteristics, as well as clinical and laboratory data did not significantly differ between these women and those form whom HPV infection was typed.
More than half of the HIV-positive women had their condition diagnosed less than a year ago (28/54). More than $60 \%$ of these women had CD4+ counts above 350 cells $/ \mathrm{mm}^{3}$ and $44 \%$ of them present viral loads above 10,000 copies $/ \mathrm{mL}$.

Overall, clearance rate was $47 \%$ (71/151). The groups among whom HPV had persisted or cleared did not differ in median age $(25.8 \pm 7.5$ years vs. $24.4 \pm 6.0$ years; $\mathrm{p}=$ $0.2)$, nor in gestational age at their 1st visit $(17.3 \pm$ 6.8 weeks vs. $17.0 \pm 7.7 ; \mathrm{p}=0.87$ ). HIV-positive and negative women did not significantly differ regarding HPV clearance rates $(48.1 \%$ vs. $46.4 \%$; $\mathrm{p}=0.87)$; but HIVpositive women took a significantly longer time $(7.0 \pm$ 3.8 months) to clear HPV, compared to those not infected by HIV ( $5.9 \pm 3.0$ months).

Univariate analyses are summarised in Table 2. HPV clearance was found to be associated with the following covariates: "to be engaged in a stable marital relationship", "to be white" (versus brown [biracial] and black), and "no previous engagement in commercial sex". "Mode of delivery", "presentation of HPV infection" (clinical/subclinical/ HPV-positive) and "HPV type" were not found to be associated with viral clearance. The group of women among whom HPV has persisted showed a higher percentage of cytological abnormalities compared to the group composed by women among whom HPV was cleared $(67.5 \%$ vs. $40.8 \% ; \mathrm{p}=0.002$ ).

Clearance rate was slightly higher in women with LRHPV than those with HR-HPV infection, but such difference was not found to be statistically significant $(20 / 39$ (51.3\%) vs. $22 / 56$ (39.3\%); $\mathrm{p}=0.25$ ).

Almost half of the women living with HIV infection cleared HPV infection during follow-up (26/54). Lower HIV viral load and higher CD4+ cell counts were found to be associated with HPV clearance. More than $75 \%$ of HIVwomen with CD4+ count over 350 cells $/ \mathrm{mm}^{3}$ cleared HPV during follow-up (20/26) and only 4 women with less than 1,000 copies/mL had a persistent HPV infection over the follow-up period (4/11).

In multivariable analysis, non-smoker women had a twofold higher chance to clear HPV (RR 2.2; IC95\% 1.1-5.0) compared with smokers. Additional data are presented in Table 3. The association between CD4+ cell count and HPV clearance did not remain statistically significant after controlling for other covariates (RR 2.0 [0.6-6.3])]. 
Table 2 Characteristics associated with HPV clearance among 151 HPV-positive women (univariate analysis)

\begin{tabular}{|c|c|c|c|c|c|}
\hline \multirow[t]{2}{*}{ Characteristics } & \multicolumn{2}{|c|}{ Persistence } & \multicolumn{2}{|c|}{ Clearance } & \multirow[t]{2}{*}{$p$} \\
\hline & $\mathrm{N}=80$ & $\%$ & $\mathrm{~N}=71$ & $\%$ & \\
\hline \multicolumn{6}{|l|}{ Marital status } \\
\hline Non-stable & 34 & 42.5 & 17 & 23.9 & $<0.05^{*}$ \\
\hline Stable & 46 & 57.5 & 54 & 76.1 & \\
\hline \multicolumn{6}{|l|}{ Race/skin color } \\
\hline White & 40 & 50.0 & 54 & 76.1 & $<0.05^{\#}$ \\
\hline Brown & 24 & 30.0 & 13 & 18.3 & \\
\hline Black & 16 & 20.0 & 4 & 5.6 & \\
\hline \multicolumn{6}{|c|}{ Years of education } \\
\hline $0-4$ & 13 & 16.2 & 7 & 9.9 & $0.68^{\#}$ \\
\hline $5-8$ & 31 & 38.8 & 30 & 42.2 & \\
\hline$>9$ & 36 & 45.0 & 34 & 47.9 & \\
\hline \multicolumn{6}{|l|}{ Menarche (yrs.) } \\
\hline$<9$ & 3 & 3.75 & 1 & 1.4 & $0.09^{\#}$ \\
\hline $9-15$ & 74 & 92.5 & 61 & 85.9 & \\
\hline$>15$ & 3 & 3.75 & 9 & 12.7 & \\
\hline
\end{tabular}

Age at 1 st sexual experience (yrs.)

$\begin{array}{lccccc}<16 & 54 & 67.5 & 39 & 54.9 & 0.19^{\#} \\ 16-20 & 23 & 28.8 & 30 & 42.3 & \\ >20 & 3 & 3.7 & 2 & 2.8 & \end{array}$

Age of 1st pregnancy (yrs.)

$\begin{array}{llllll}<16 & 22 & 27.5 & 11 & 15.5 & 0.17^{*} \\ 16-20 & 38 & 47.5 & 36 & 50.7 & \\ >20 & 20 & 25.0 & 24 & 33.8 & \end{array}$

Parity

$\begin{array}{lccccc}0 & 40 & 50.0 & 37 & 52.1 & 0.83^{\#} \\ 1-3 & 38 & 47.5 & 30 & 42.3 & \\ \geq 4 & 2 & 2.5 & 4 & 5.6 & \end{array}$

Lifetime no. of sex partners

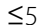

6-10

$11-20$

$>20$

Sex partners (last 12 mos.)

$\begin{array}{lccccc}<3 & 75 & 93.8 & 68 & 95.8 & 1.0^{\#} \\ \geq 3 & 5 & 6.2 & 3 & 4.2 & \\ \text { HIV-positive status } & 28 & 35.0 & 26 & 36.6 & 0.84^{*} \\ \text { Smoking } & 22 & 27.5 & 15 & 21.1 & 0.36^{*} \\ \text { Drug use } & & & & & \\ \quad \text { None } & 59 & 73.8 & 59 & 83.1 & 0.39^{\#} \\ \quad \text { Marijuana } & 14 & 17.5 & 10 & 14.1 & \\ \quad \text { Cocaine/crack } & 7 & 8.7 & 2 & 2.8 & \\ \text { Alcohol } & 15 & 18.8 & 5 & 7.0 & 0.053^{\#}\end{array}$

Table 2 Characteristics associated with HPV clearance among 151 HPV-positive women (univariate analysis) (Continued)

\begin{tabular}{llllll}
\hline Previous STD & 30 & 37.5 & 24 & 33.8 & $0.64^{*}$ \\
Sexual partner with STD ${ }^{1}$ & 18 & 22.5 & 13 & 18.3 & $0.52^{*}$ \\
$\begin{array}{l}\text { Mode of delivery } \\
\quad \text { Cesarean section }\end{array}$ & 37 & 46.2 & 27 & 38.0 & 0.33 \\
$\quad$ Vaginal & 43 & 53.8 & 44 & 62.0 & \\
HPV infection type & & & & & \\
$\quad$ Subclinical/clinical & 60 & 75.0 & 51 & 71.8 & 0.66 \\
$\quad$ HPV-positive & 20 & 25.0 & 20 & 28.2 & \\
HPV type & & & & & \\
$\quad$ High risk & 34 & 64.1 & 22 & 54.4 & 0.3 \\
$\quad$ Low risk & 19 & 35.9 & 20 & 47.6 & \\
\hline
\end{tabular}

Ribeirão Preto, 2007-2010.

${ }^{*}$ Chi-square test; ${ }^{\#}$ Fisher Exact Test; ${ }^{1}$ Referred by women.

HPV clearance was made evident between the 2nd and the 3rd (postpartum) visits in $84.5 \%$ of women who cleared HPV infection (60/71), compared to $15.5 \%$ during the 1st and 2nd visits (antenatal care) (11/71). Such difference was statistically significant for women, irrespectively of their HIV status, as well as when analyses were stratified by HIV status (Table 4). More than 70\%

Table 3 Characteristics associated with HPV clearance among 151 HPV-positive women (multivariable analysis)

Variables Adjusted RR (Cl95\%)*

\section{Age (years)}

$>25$

$\leq 25$

$0.9(0.5-1.5)$

Smoking

Yes

No

$2.2(1.1-5.0)$

Mode of delivery

Cesarean section

Vaginal

$1.1(0.6-1.9)$

HIV status

Positive

Negative

$1.0(0.6-1.7)$

Nature of HPV infection

Subclinical/clinical

HPV-positive

$1.4(0.7-2.7)$

HPV type

High risk

Low risk

$1.4(0.9-2.3)$

Ribeirão Preto, 2007-2010.

RR: Relative risk; Cl95\%: Confidence interval 95\%.

*Adjusted for all variables listed in table. 
Table 4 HPV clearance during pregnancy and postpartum period (overall and according to HIV status)

\begin{tabular}{|c|c|c|c|c|c|c|c|c|c|}
\hline \multirow[t]{2}{*}{$\begin{array}{l}\text { Period of } \\
\text { clearance }\end{array}$} & \multicolumn{3}{|c|}{$\begin{array}{l}\text { All women } \\
\qquad(\mathrm{N}=71)\end{array}$} & \multicolumn{3}{|c|}{$\begin{array}{l}\text { HIV-positive women } \\
\qquad(\mathrm{N}=26)\end{array}$} & \multicolumn{3}{|c|}{$\begin{array}{l}\text { HIV-negative women } \\
\qquad(\mathrm{N}=45)\end{array}$} \\
\hline & $\mathrm{N}$ & $\%$ & IC95\% & $\mathrm{N}$ & $\%$ & IC95\% & $\mathrm{N}$ & $\%$ & IC95\% \\
\hline Pregnancy & 11 & 15.5 & $8-26$ & 7 & 26.9 & $12-48$ & 4 & 8.9 & $3-22$ \\
\hline Postpartum period & 60 & 84.5 & $74-92$ & 19 & 73.1 & $52-88$ & 41 & 91.1 & $78-97$ \\
\hline
\end{tabular}

of HIV-negative and 90\% of HIV-positive women cleared HPV during the postpartum period.

\section{Discussion and conclusions}

Overall clearance rate in this study was $47 \%$, which is in agreement with previous findings, among both pregnant $[27,36]$ and non-pregnant women [37-39]. In a previous Spanish study [36], pregnant women at high-risk of HPV exposure had a clearance rate up to the post-partum visit $(53.8 \%)$ roughly comparable to our findings. Divergent findings could be due to the analysis of populations with different composition in terms of their genetic background, nutritional and health status, as well as longer or shorter follow-up periods. The very definition of viral clearance has been varied in different studies. Banura et al. [24] identified higher clearance rates in primiparous women from Uganda than those made evident by our study, but their study differs from ours due to the fact that the vast majority of women recruited by them did not have any other medical conditions. Another difference between our studies is that the study in Uganda computed the number of actual infections cleared (discriminated by viral subtypes) instead of the number of women who cleared HPV infection.

High HPV clearance rates between 68.3 and 80.7\% have been reported among non-pregnant women without cytological abnormalities, under a longer follow-up period $[13,35,40,41]$. On the other hand, Banura et al. [42] documented viral clearance in $31.2 \%$ of Ugandan non-pregnant women. The authors considered that the low clearance rate made evident by their study was, in part, due to new infections acquired by subjects during the intervals between subsequent visits.

The current study identified a higher HPV clearance rate during the postpartum period for both HIV-positive and negative women, compared to the period covered by the antenatal visits. These findings corroborate the results previously reported by Nobbenhuis et al. [27], who found lower HPV positivity in women with abnormal cytology after delivery, compared to clearance observed over all gestational trimesters. Data eventuating from a re-analysis of a German cohort documented a higher risk for HPV infection in pregnant vis-à-vis puerperal women [28].

Cervical trauma during delivery may be associated with lower HPV-infection rates during postpartum. Previous studies identified higher regression rates of HPV- related lesions among women who delivered vaginally compared to those who had Caesarean sections $[43,44]$, in contrast to other studies, which found similar regression rates for women who had vaginal or c-section deliveries [45,46]. Ours is the first study to assess HPV clearance in the context of different modes of delivery, but our findings did not make evident any significant difference between them respecting HPV clearance. (This may be, however, due to the lack of statistical power to fully explore such hypothesis).

More than $70 \%$ of HIV-positive women enrolled in the study cleared HPV over time, a higher rate than has been previously reported among non-pregnant women. Denny et al. [47] observed an HPV clearance of $6 \%$ of SouthAfrican non-pregnant women living with HIV, over an 18-month follow-up period. An Italian study reported a 22.8\% HPV clearance rate in HIV-positive women over 14 months [19]. Our favourable evolution might therefore be secondary to good immunologic status or relatively low frequency of cytological abnormalities in HIV-positive women enrolled in our study.

Brazilian health care system guarantees the full access to free antiretroviral therapy to any eligible patient according to criteria which are similar to the updated criteria issued by the World Health Organization (WHO). More than $90 \%$ of our patients have used this therapy during pregnancy, which might influence our results. A recent study has demonstrated that highly active antiretroviral therapy may increase the clearance of some oncogenic HPV types [48]. These factors may have confounded the association between HIV status and HPV persistence.

Ours is the first study to assess HPV clearance among HIV-positive women during pregnancy and postpartum. Minkoff et al. [30] compared HPV prevalence and incidence in pregnancy and puerperium in HIV-positive women. The authors identified a higher incidence rate for HPV infection in the postpartum period.

In the HER Study (HIV Epidemiology Research), which included more than 500 HIV-positive women, higher $\mathrm{CD} 4+$ cell counts were found to be associated with a higher HPV clearance [22]. Rowhani-Rahbar et al. [21] identified that HPV clearance was inversely proportional to HIV viral load and less likely to occur in women with lower CD4+ cell count, especially among those with $\mathrm{CD} 4+$ counts bellow 200 cells $/ \mathrm{mm}^{3}$. A 
South-African study found that low CD4+ count was associated with a higher HPV infection incidence, but no association with clearance was made evident by it. Clearance was found to be exclusively associated with HIV viral load [47]. Furthermore, it has been suggested that HIV-HPV coinfections have a broader impact on immunity, beyond their impact on CD4+ count [21]. In the current study, CD4+ cell count was not found to be associated with HPV clearance.

We further analysed the database in order to assess a putative linear relationship between successive categories of CD4+ counts $(<200,200-350,350-500,500+)$ and HPV clearance (data not shown). Unfortunately, we did not observe any gradient, either because it does not exist or because of our small sample size (beta error).

The study assessed HPV types using a modest set of primers and HPV type-persistence was not assessed. Further studies, profiting from a comprehensive variety of HPV primers and a follow-up of HPV-types incidence/clearance over time is sorely needed in order to complement and validate our findings.

In longitudinal studies, clearance rates and median infection duration might be underestimated due to leftcensoring of infections present at the beginning of the study and right-censoring of infections that have not been cleared until the end of follow-up. The current study had a relatively short follow-up and intervals between visits, which were limited to pregnancy and postpartum. Such a short period of time (secondary to the logistic of the referral service) might compromise our ability to assess HPV evaluation. Women might have cleared their infection between visits, and it is not possible to specify the precise moment during which clearance may take place. The association between HPV and HIV coinfection might be underestimated in which case a longer follow-up period would be necessary to properly assess it over time.

Our findings should not be generalised to other groups of pregnant women, due to its small sample size, short follow-up time, and the fact that our study enrolled women from a tertiary referral care unit. Other sexually transmitted infections were not investigated such as Chlamydia trachomatis. Therefore, some unmeasured confounding may have affected the adjusted risk ratios.

HPV pathophysiology is especially complex due to the impossibility to fully differentiate persistent infections from those which might have occurred during the interval of two consecutive visits. Besides such caveat, a negative HPV test may not represent the full elimination of the virus, since latent infection may remain elusive from the perspective of both clinical and laboratory assessments. According to Schiffman et al. [49], HPV reappearance after a period of latency may be common, even in the absence of immunosuppression. These controversial aspects, combined with the transient nature HPV infection may interfere on any assessment of the natural history of HPV infection.

The current study aimed to better assess some controversial aspects of HPV's natural history. Postpartum period appears to be a period of significant decline of HPV infection, among both HIV-negative and positive women. The mode of delivery does not seem to influence this decline. A better understanding of HPV dynamics may help to identify women at higher risk of developing HPV-related lesions during antenatal care, contributing to prevention of cervical cancer, especially among HIV-positive women, among whom such cancers tend to be especially aggressive and harmful.

\section{Abbreviations}

HPV: Human papillomavirus; HIV: Human immunodeficiency virus; PCR: Polymerase chain reaction; LR-HPV: Low-risk HPV; HR-HPV: High-risk HPV.

\section{Competing interests}

The authors declare that they have no competing interests.

\section{Authors' contributions}

EMJ and SMQ conceived and designed the project, and analysed data. PPSM participated in data collection. GD and FIB provided guidance on this project. RTS and AYY carried out the PCR analysis. RAAM contributed to the data analysis and in the review process. All authors have been involved in drafting or revising the manuscript and have approved its final version.

\section{Acknowledgements}

We thank Neilane Bertoni for her feedback in statistical analyses.

\section{Author details}

${ }^{1}$ ICICT/ENSP - Fundação Oswaldo Cruz - FIOCRUZ, Biblioteca de Manguinhos suite 229, Av. Brasil 4365, Rio de Janeiro RJ 21045-900, Brazil. ${ }^{2}$ CAPES Visiting scholar, Imperial College London, London, UK. ${ }^{3}$ Faculdade de Medicina de Ribeirão Preto, Universidade de São Paulo, Sao Paulo, Brazil. ${ }^{4}$ Instituto de Ensino e Pesquisa da Santa Casa de, Belo Horizonte, Brazil.

Received: 3 May 2013 Accepted: 26 November 2013

Published: 1 December 2013

\section{References}

1. Bruni L, Diaz M, Castellsagué M, Ferrer E, Bosch FX, de Sanjosé S: Cervical Human Papillomavirus Prevalence in 5 continents: meta-analysis of 1 million women with normal cytological findings. J Infect Dis 2010, 202:1789-1799.

2. Ho GY, Bierman R, Beardsley L, Chang CJ, Burk RD: Natural history of cervicovaginal papillomavirus infection in young women. $N$ Engl J Med 1998, 338:423-428.

3. Plummer M, Schiffman M, Castle PE, Maucort-Boulch D, Wheeler CM: A 2year prospective study of human papillomavirus persistence among women with a cytological diagnosis of atypical squamous cells of undetermined significance or low-grade squamous intraepithelial lesion. J Infect Dis 2007, 195:1582-1589.

4. Rodriguez AC, Schiffman M, Herrero R, Wacholder S, Hildesheim A, Castle PE, Solomon D, Burk R: Proyecto epidemiológico Guanacaste group: rapid clearance of human papillomavirus and implications for clinical focus on persistent infections. J Natl Cancer Inst 2008, 100:513-517.

5. Winer RL, Hughes JP, Feng Q, Xi LF, Cherne S, O'Reilly S, Kiviat NB, Koutsky LA: Early natural history of incident type-specific human papillomavirus in newly sexually active young women. Cancer Epidemiol Biomarkers Prev 2011, 20:699-707.

6. Kjaer SK, van den Brule AJC, Paull G, Svare El, Sherman ME, Thomsen BL, Suntum M, Bock JE, Poll PA, Meijer CJ: Type specific persistence of high risk human papillomavirus (HPV) as indicator of high grade cervical 
squamous intraepithelial lesions in young women: population based prospective follow up study. BMJ 2002, 325:572-578.

7. Koshiol J, Lindsay L, Pimenta JM, Poole C, Jenkins D, Smith JS: Persistent human papillomavirus infection and cervical neoplasia: a systematic review and meta-analysis. Am J Epidemiol 2008, 168:123-137

8. Stanley M: Pathology and epidemiology of HPV infection in females. Gynecol Oncol 2010, 117:S5-S10.

9. Louvanto K, Syrjanen KJ, Rintala MA, Grénman SE, Syrjanen SM: Human papillomavirus and predictors of cervical intraepithelial neoplasia among young mothers in a prospective follow-up study. Acta Obstet Gynecol Scand 2011, 90:167-173.

10. Naucler P, Ryd W, Tomberg S, Strand A, Wadell G, Elfgren K, Rådberg T, Strander B, Johansson B, Forslund O, Hansson BG, Rylander E, Dillner J: Human papillomavirus and Papanicolaou tests to screen for cervical cancer. N Engl J Med 2007, 357:1589-1597.

11. Castle PE, Rodriguez AC, Burk RD, Herrero R, Wacholder S, Alfaro M, Morales J, Guillen D, Sherman ME, Solomon D, Schiffman M: Proyecto Epidemiológico Guanacaste (PEG) Group: Short term persistence of human papillomavirus and risk of cervical precancer and cancer: population based cohort study. BMJ 2009, 339:b2569.

12. Molano M, Van den Brule A, Plummer M, Weiderpass E, Posso H, Arslan A, Meijer CJ, Muñoz N, Franceschi S: HPV Study Group: Determinants of clearance of human papillomavirus infections in Colombian women with normal cytology: a population-based, 5-year follow-up study. Am J Epidemiol 2003, 158:486-494.

13. Oh JK, Ju YH, Franceschi S, Quint W, Shin HR: Acquisition of new infection and clearance of type-specific human papillomavirus infections in female students in Busan, South Korea: a follow-up study. BMC Infect Dis 2008, 8:13-18.

14. Kadish AS, Ho GY, Burk RD, Wang Y, Romney SL, Ledwidge R, Angeletti RH: Lymphoproliferative responses to human papillomavirus (HPV) type 16 proteins E6 and E7: outcome of HPV infection and associated neoplasia. J Natl Cancer Inst 1997, 89:1285-1293.

15. Song SH, Lee JK, Lee NW, Saw HS, Kang JS, Lee KW: Interferon- $\gamma$ (IFN- $\gamma$ ): a possible prognostic marker for clearance of high-risk human papillomavirus (HPV). Gynecol Oncol 2008, 108:543-548.

16. Einstein $\mathrm{KH}$, Schiller JT, Viscidi RP, Strickler HD, Coursaget $P$, Tan T, Halsey N, Jenkins D: Clinician's guide to human papillomavirus immunology: knowns and unknowns. Lancet Infect Dis 2009, 9:347-356.

17. Sun XW, Kuhn L, Ellerbrock TV, Chiasson MA, Bush TJ, Wright TC Jr: Human papillomavirus infection in women infected with the human immunodeficiency virus. N Engl J Med 1997, 337:1343-1349.

18. Ahdieh L, Klein RS, Burk R, Cu-Uvin S, Schuman P, Duerr A, Safaeian M, Astemborski J, Daniel R, Shah K: Prevalence, incidence and type-specific persistence of human papillomavirus in human immunodeficiency virus (HIV)-positive and HIV-negative women. J Infect Dis 2001, 184:682-690.

19. Branca M, Garbuglia AR, Benedetto A, Cappiello T, Leoncini L, Migliore G, Agarossi A, Syrjänen K: DIANAIDS Collaborative Study Group: Factors predicting the persistence of genital human papillomavirus infection and PAP smear abnormality in HIV-positive and HIV-negative women during prospective follow-up. Int J STD Aids 2003, 14:417-425.

20. Strickler HD, Burk RD, Fazzari M, Anastos K, Minkoff H, Massad LS, Hall C, Bacon M, Levine AM, Watts DH, Silverberg MJ, Xue X, Schlecht NF, Melnick S, Palefsky JM: Natural history and possible reactivation of human papillomavirus in human immunodeficiency virus-positive women. J Natl Cancer Inst 2005, 97:577-586.

21. Rowhani-Rahbar A, Hawes SE, Sow PS, Toure P, Feng Q, Dem A, Dembele B, Critchlow CW, N'Doye I, Kiviat NB: The impact of HIV status and type on the clearance of human papillomavirus infection among Senegalese women. J Infect Dis 2007, 196:887-894.

22. Paramsothy P, Jamieson DJ, Heilig CM, Schuman PC, Klein RS, Shah KV Rompalo AM, Cu-Uvin S, Duerr A: The effect of highly active antiretroviral therapy on human papillomavirus clearance and cervical cytology. Obstet Gynecol 2009, 113:26-31.

23. Takakuwa K, Mitsui T, Iwashita M, Kobayashi I, Suzuki A, Oda T, Torii Y, Matsumoto M, Yahata G, Tanaka K: Studies on the prevalence of human papillomavirus in pregnant women in Japan. J Perinat Med 2006, 34:77-79.

24. Banura C, Franceschi S, van Doorn $L$, Arslan A, Kleter B, Wabwire-Mangen F, Mbidde EK, Quint W, Weiderpass E: Prevalence, incidence and clearance of human papillomavirus infection among young primiparous pregnant women in Kampala, Uganda. Int J Cancer 2008, 123:2180-2187.
25. Domza G, Gudleviciene Z, Didziapetriene J, Valuckas KP, Kazbariene B, Drasutiene G: Human papillomavirus infection in pregnant women. Arch Gynecol Obstet 2010, 20:1405-1410.

26. Fife KH, Katz BP, Brizendine EJ, Brown DR: Cervical human papillomavirus deoxyribonucleic acid persists throughout pregnancy and decreases in the postpartum period. Am J Obstet Gynecol 1999, 180:1110-1114.

27. Nobbenhuis MAE, Helmerhorst TJM, van den Brule AJC, Rozendaal L, Bezemer PD, Voorhorst FJ, Meijer CJ: High-risk human papillomavirus clearance in pregnant women: trends for lower clearance during pregnancy with a catch-up postpartum. Br J Cancer 2002, 87:75-80.

28. Ziegler A, Kastner C, Chang-Claude J: Analysis of pregnancy and other factors on detection of human papillomavirus (HPV) infection using weighted estimating equations for follow-up data. Statist Med 2003, 22:2217-2233.

29. Sarkola ME, Grénman SE, Rintala MA, Syrjanen KJ, Syrjanen SM: Effect of second pregnancy on maternal carriage and outcome of high-risk human papillomavirus (HPV). Experience from the prospective finnish family HPV study. Gynecol Obstet Invest 2009, 67:208-216.

30. Minkoff H, Shen X, Watts DH, Leighty R, Hershow R, Palefsky J, Tuomala R, Neu N, Zorrilla CD, Paul M, Strickler H: Relationship of pregnancy to human papillomavirus among human immunodeficiency virus-infected women. Obstet Gynecol 2006, 108:953-960.

31. de Roda-Husman AM, Walboomers JMM, van den Brule AJC, Meijer CJLM, Snijders PJF: The use of general primers GP5 and GP6 elongated at their 3 ' ends with adjacent highly conserved sequences improves human papillomavirus detection by PCR. J Gen Virology 1995, 76:1057-1062.

32. Mant C, Kell B, Best JM, Cason J: Polymerase chain reaction protocols for the detection of DNA from mucosal human papillomavirus types $-6,-11$, $-16,-18,-31$ and -33. J Virol Methods 1997, 66:169-178.

33. Bernard HU, Chan SY, Manos MM, Ong CK, Villa LL, Delius H, Peyton CL, Bauer HM, Wheeler CM: Identification and assessment of known and novel human papillomaviruses by polymerase chain reaction amplification, restriction fragment length polymorphisms, nucleotide sequence and phylogenetic algorithms. J Infect Dis 1994, 170:1077-1085.

34. Winer RL, Hughes JP, Feng Q, O'Reilly S, Kiviat NB, Holmes KK, Koutsky LA: Condom use and the risk of genital human papillomavirus infection in young women. N Engl J Med 2006, 354:2654-54.

35. Goodman MT, Shvetsov YB, McDuffie K, Wilkens LR, Zhu X, Thompson PJ, Ning L, Killeen J, Kamemoto L, Hernandez BY: Prevalence, acquisition, and clearance of cervical human papillomavirus infection among women with normal cytology: Hawaii Human Papillomavirus Cohort Study. Cancer Res 2008, 68:8813-8824.

36. Castellsagué X, Drudis T, Cañadas MP, Goncé A, Ros R, Pérez JM, Quintana MJ, Muñoz J, Albero G, de Sanjosé S, Bosch FX: Human papillomavirus (HPV) infection in pregnant women and mother-to-child transmission of genital HPV genotypes: a prospective study in Spain. BCM Infect Dis 2009, 9:74-84.

37. Sellors JW, Karwalajtys TL, Kaczorowski J, Mahony JB, Lytwyn A, Chong S, Sparrow J, Lorincz A: Survey of HPV in Ontario Women Group: Incidence, clearance and predictors of human papillomavirus infection in women. CMAJ 2003, 168:421-425.

38. Richardson H, Abrahamowicz M, Tellier PP, Kelsall G, du Berger R, Ferenczy A, Coutlée F, Franco EL: Modifiable risk factors associated with clearance of type-specific cervical human papillomavirus infections in a cohort of university students. Cancer Epidemiol Biomarkers Prev 2005, 14:1149-1156.

39. Lai CH, Chao A, Chang CJ, Chao FY, Huang HJ, Hsueh S, Lin CT, Cheng HH, Huang CC, Yang JE, Wu TI, Chou HH, Chang TC: Host and viral factors in relation to clearance of human papillomavirus infection: a cohort study in Taiwan. Int J Cancer 2008, 123:1685-1692.

40. Rosa MI, Fachel JMG, Rosa DD, Medeiros LR, Igansi CR, Bozzetti MC: Persistence and clearance of human papillomavirus infection: a prospective cohort study. Am J Obstet Gynecol 2008, 199:617.e1-617.e7

41. Bae J, Seo S-S, Park Y-S, Dong SM, Kang S, Myung SK, Park SY: Natural history of persistent high-risk human papillomavirus infections in Korean women. Gynecol Oncol 2009, 115:75-80.

42. Banura C, Sandin S, van Doorn L, Quint W, Kleter B, Wabwire-Mangen F, Mbidde EK, Weiderpass E: Type-specific incidence, clearance and predictors of cervical human papillomavirus infections (HPV) among young women: a prospective study in Uganda. Infect Agent Cancer 2010, 5:7.

43. Ahdoot D, van Nostrand KM, Nguyen NJ, Tewari DS, Kurasaki T, DiSaia PJ, Rose GS: The effect of route of delivery on regression of abnormal 
cervical cytologic findings in the postpartum period. Am J Obstet Gynecol 1998, 178:1116-20.

44. Ueda Y, Enomoto T, Miyatake T, Yoshino K, Fujita M, Miyake T, Fujiwara K, Muraji M, Kanagawa T, Kimura T: Postpartum outcome of cervical intraepithelial neoplasia in pregnant women determined by route of delivery. Reprod Sci 2009, 16:1034-9.

45. Yost NP, Santoso JT, McIntire DD, lliya FA: Postpartum regression rates of antepartum cervical intraepithelial neoplasia II and III lesions.

Obstet Gynecol 1999, 93:359-62.

46. Kaneshiro BE, Acoba JD, Holzman J, Wachi K, Carney ME: Effect of delivery route on natural history of cervical dysplasia. Am J Obstet Gynecol 2005, 192:1452-1454.

47. Denny L, Boa R, Williamson AL, Allan B, Hardie D, Stan R, Myer L: Human papillomavirus infection and cervical disease in human immunodeficiency virus-1-infected women. Obstet Gynecol 2008, 111:1380-7.

48. Blitz S, Baxter J, Raboud J, Walmsley S, Rachlis A, Smaill F, Ferenczy A, Coutlée F, Hankins C, Money D: Canadian Women's HIV Study Group: Evaluation of HIV and highly active antiretroviral therapy on the natural history of human papillomavirus infection and cervical cytopathologic findings in HIV-positive and high-risk HIV-negative women. J Infect Dis 2013, 208(3):454-62.

49. Schiffman M, Wentzensen N, Wacholder S, Kinney W, Gage JC, Castle PE: Human papillomavirus testing in the prevention of cervical cancer. J Natl Cancer Inst 2011, 103:368-83.

doi:10.1186/1471-2334-13-564

Cite this article as: Jalil et al:: HPV clearance in postpartum period of HIV-positive and negative women: a prospective follow-up study. BMC Infectious Diseases 2013 13:564.

\section{Submit your next manuscript to BioMed Central and take full advantage of:}

- Convenient online submission

- Thorough peer review

- No space constraints or color figure charges

- Immediate publication on acceptance

- Inclusion in PubMed, CAS, Scopus and Google Scholar

- Research which is freely available for redistribution 